\title{
Enhanching Organizatonal Citizenship Behavior by Strengthening Leadership Style and Decision Making
}

\author{
Griet Helena Laihadand, Henny Suharyati
}

\begin{abstract}
Nowadays there is a lot of discussion about extra mile behavior which refers to Organizational Citizenship Behavior $(O C B)$ that is able to contribute to the progress of the organization. This research is carried out to see some factors that can increase $\mathrm{OCB}$. The study is designed to determine the effect of leadership style and decision making toward $O C B$ of the teacher in pre-school. To achieve the research objectives, the survey method is employed. It reveals that both leadership style and decision making have a direct influence on $\mathrm{OCB}$. It is concluded that enhancing organizational citizenship behavior of the teacher in pre-school would be strengthening them.
\end{abstract}

Index Terms: organizational citizenship behavior, leadership style, decision making.

\section{INTRODUCTION}

In early childhood, all the functions and abilities of children are growing very rapidly that require contributions from adults to provide appropriate stimulation for its ability to be actualized and develop optimally. Teachers or early childhood educators were generally similar to tutors, who has the charisma, the ability to design learning programs, able to organize and manage the classroom effectively and efficiently as well as an adult figure who can consciously educate, teach, guide and make teachers as a profession that requires special expertise [1]. This indicates how important the role of a teacher as an educator. In addition to formal education, teachers are expected not only to be able to carry out their task performance but want to provide extra services/extra mile such as help, tolerate, voluntarily carry out tasks outside their working hours, have the initiative to develop themselves, are actively involved and participate in advancing school, and are able to use work time effective. Teachers with positive behaviors mentioned above can be interpreted as having a high Organizational Citizenship Behavior (OCB).

OCB is one of the main topics that get practitioners and researchers attention and interest. Many studies have been done to identify the factors that effect OCB such as Organizational Culture, personality, work satisfaction, and other variables. The Factors affecting teachers' OCB in this research include Leadership Style and decision-making.

Revised Manuscript Received on April 25, 2019.

Griet Helena Laihad, Prodi Administrasi Pendidikan, Pascasarjana Universitas Pakuan, JalanPakuan No. 1 Bogor, Indonesia

HennySuharyati, Prodi Administrasi Pendidikan, Pascasarjana Universitas Pakuan, JalanPakuan No. 1 Bogor, Indonesia facilitators, tutors who have the characteristics as a figure

OCB is defined by Colquitt, et.al [1] who basically has the same meaning as voluntary employee activities that may or may not be the reward but that contribute to the organization by improving the overall quality of the setting in which work takes place. The importance of OCB for the achievement of organizational goals is also expressed by Colquitt, et.al [2] that the most valuable employees in any organization are those who go the extra mile. It is also Mac Shane, et. Al [3] stating that one of the defining characteristics of standard employees is that they perform beyond task performance standards or expectations. They will go the extra step, or maybe even the extra mile, to support the interest of organizations.

Leadership style, Mullins, [4] defined as the way in which the functions of leadership are carried out, the way in which the manager typically behaves toward the member of the group. According to Goetsch, et.al [5] leadership style has to do with how people interact with those they seek to lead. Principals who have a democratic leadership style involve teachers in each activity and provide the proper capacity authority will increase positive behavior of teachers such as OCB. Good cooperation between the principal and the teacher as a team wherever the principal is one of the most important determinants to give the effectiveness of learning in the classroom and to create a conducive climate through his leadership style. This is according to Robbins, et.al [6] that effective group work is related to the pair that fits between the leader's style of interacting with his subordinates and the level of activity in which the situation influences and controls the leader. Furthermore, Owens [7] states that to achieve success and provide targeted improvement, leaders must help staff strategic actions based on detected needs. The school principal also needs to identify the positive behavior of his teachers who will support the school effectiveness of the school leader to identify the supportive behaviors that build positive relationships.

Decision-making, Certo [8], is a process of choosing the best alternative for reaching objectives. Teachers were able to determine the best option for achieving the goal will realize the importance of developing the OCB for the progress of the school. The spirit to continue working and achieving will make the teacher feel responsible for carrying out other tasks in the success of the organization where he works. Bogler, et.al. [9] say that good decision making will help individuals, groups, and organizations achieve good goals and performance. The teacher has a high OCB regardless of the leadership role. 
Democratic principles where decision making is not only unilateral but also involve teachers in each activity and provide authority in accordance with their capacity will lead to satisfaction in the work so as to foster positive behavior of teachers. Leaders who agree with the participation leader model have a high level of satisfaction and productivity compared to leaders who do not use this model.

Based on the above, the researcher is interested in taking on the issue:" Can OCB of teacher's in pre-school enhanced by strengthening leadership style anddecision making?"

\section{METHOD}

This study used a quantitative approach with survey method and path analysis (path analysis) to analyze the influence of one variable to another variable. There are two exogenous variables, leadership style $(\mathrm{X})$ and decision making ( $\mathrm{Z}$ ) for OCB and two endogenous variables, decision-making $(\mathrm{Z})$ and OCB (Y).

The population is an accredited private pre-school teacher in the six areas at Bogor city. Based on Slovin's sampling method, obtained a sample of 175 people. Sampling technique using proportional random sampling and data collection techniques using instruments such as questionnaires with test and non-test.The validity test using Product Moment for non-test instruments.

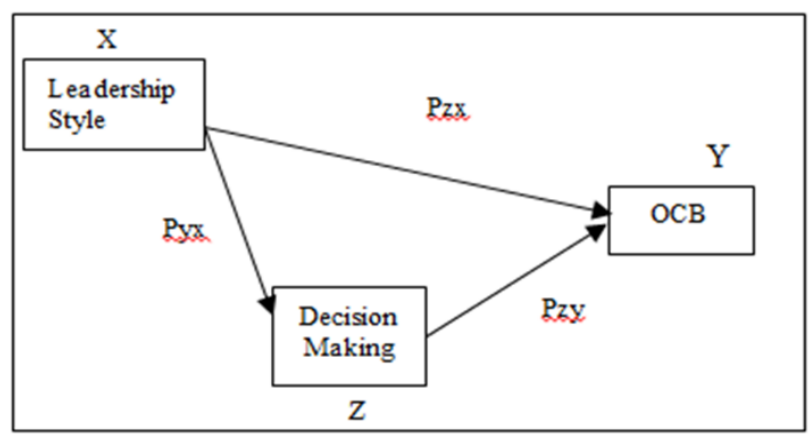

Fig 1. Research design with the path analyse

Data analysis techniques combine (a) a description of the data, (b) testing data analysis requirements, and (c) test the research hypothesis. The descriptive analysis is presented in the frequency table and histogram diagram, normality test using Liliefors test, test, and test linearity regression significance using the F test. Preceded by the correlation between variables and the relationship between the criterion variable Guilford (1956). Analysis of the path analysis is used to determine (1) the direct positive influence of leadership style on OCB, (2) direct positive influence of leadership style toward decision making, and (3) direct positive influence toward decision making toward OCB.

\section{RESULTS AND DISCUSSION}

In case of the path coefficients, obtained for first structural the following results: Leadership Styles $(\mathrm{X})$ direct positive influence toward OCB $(\mathrm{Y})$ about $=0.516(\mathrm{t}=8.320 ; \mathrm{p}$ $<0,01)$ was significant. Decision-making $(\mathrm{Z})$ direct positive influence toward OCB $(\mathrm{Y})$ about $=0.289(\mathrm{t}=4.655 ; \mathrm{p}<0,01)$ was significant (see Table 1).

\begin{tabular}{|c|c|c|c|c|c|c|}
\hline \multicolumn{7}{|c|}{ Coefficients $^{\mathrm{a}}$} \\
\hline & \multirow{2}{*}{ Model } & \multicolumn{2}{|c|}{$\begin{array}{l}\text { Unstandardized } \\
\text { Coefficients }\end{array}$} & \multirow{2}{*}{\begin{tabular}{|c|}
$\begin{array}{c}\text { Standardized } \\
\text { Coefficients }\end{array}$ \\
Beta \\
\end{tabular}} & \multirow[b]{2}{*}{$\mathrm{t}$} & \multirow[b]{2}{*}{ Sig. } \\
\hline & & B & Std. Error & & & \\
\hline \multirow[t]{3}{*}{1} & (Constant) & 42.082 & 6.206 & & 6.781 & .000 \\
\hline & $\begin{array}{l}\text { Leadership } \\
\text { Styles }\end{array}$ & .487 & .059 & .516 & 8.320 & .000 \\
\hline & $\begin{array}{l}\text { Decision } \\
\text { Making }\end{array}$ & .983 & .211 & .289 & 4.655 & .000 \\
\hline \multicolumn{7}{|c|}{ a. Dependent Variable: OCB } \\
\hline
\end{tabular}

Table 2. Rsquare of the first structural

Model Summary
\begin{tabular}{|c|c|c|c|c|}
\hline Model & $\mathrm{R}$ & R Square & $\begin{array}{c}\text { Adjusted R } \\
\text { Square }\end{array}$ & $\begin{array}{c}\text { Std. Error of the } \\
\text { Estimate }\end{array}$ \\
\hline 1 & $.704^{\mathrm{a}}$ & .496 & .490 & 8.166 \\
\hline
\end{tabular}

a. Predictors: (Constant), Decision Making, Leadership Styles

The path coefisien of the secondary structural the following result: Leadership Styles (X) direct positive influence toward Decision Making $(\mathrm{Z})$ about $0.489(\mathrm{t}=$ 7.381 $>\mathrm{t}$ table $=2,604(\mathrm{p}<0: 01)$ was significant $($ see Table 1$)$.

Table3. Path coefisien of the secondary structural

\begin{tabular}{|c|c|c|c|c|c|c|}
\hline \multicolumn{7}{|c|}{ Coefficients $^{\mathrm{a}}$} \\
\hline & \multirow{2}{*}{ Model } & \multicolumn{2}{|c|}{$\begin{array}{l}\text { Unstandardized } \\
\text { Coefficients }\end{array}$} & \multirow{2}{*}{$\begin{array}{c}\begin{array}{c}\text { Standardized } \\
\text { Coefficients }\end{array} \\
\text { Beta }\end{array}$} & \multirow[b]{2}{*}{$\mathrm{t}$} & \multirow[b]{2}{*}{ Sig. } \\
\hline & & B & Std. Error & & & \\
\hline \multirow[t]{2}{*}{1} & (Constant) & 9.768 & 2.106 & & 4.637 & .000 \\
\hline & $\begin{array}{c}\text { Leadership } \\
\text { Styles }\end{array}$ & .136 & .018 & .489 & 7.381 & .000 \\
\hline
\end{tabular}

Table4. Rsquare of the secondary structural

Model Summary
\begin{tabular}{|c|c|c|c|c|}
\hline Model & $\mathrm{R}$ & R Square & $\begin{array}{c}\text { Adjusted R } \\
\text { Square }\end{array}$ & $\begin{array}{c}\text { Std. Error of the } \\
\text { Estimate }\end{array}$ \\
\hline 1 & $.489^{\mathrm{a}}$ & .239 & .235 & 2.939 \\
\hline
\end{tabular}

a. Predictors: (Constant), Leadership Styles

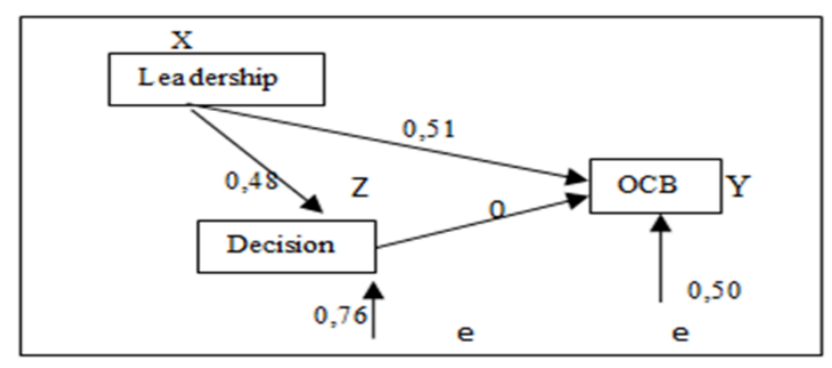

Fig 2. Fit model 
Based on above that model of the path can be describe, first, the Leadership Styles direct positive influence toward OCB pre-school teacher, and the Decision making direct positive influence toward OCB with $\mathrm{Y}=0,516 \mathrm{X}+0,289 \mathrm{Z}+$ $0,504 \mathrm{e} 2 ; \mathrm{R} 2 \times 3 \times 2 \times 1=0,496$. Therefore, it can be said that the OCB of teachers in pre-school increased because of the effect of increasing Leadership Styles and Decision making. It is also be said that $49.6 \%$ of the variance in OCB originates from leadership style and decision making when the determination coefficient $(\mathrm{R} 2=0.496)$ is taken into consideration. Second, the Leadership Styles direct positive influence toward Decision Making with $\mathrm{Z}=0,489 \mathrm{X} 1+$ $0,761 \mathrm{e} 1 ; \mathrm{R} 2 \mathrm{xy}=0,239$. (Fig. 2). It can be said that decision making of teachers in pre-school increased because of the effect of increasing leadership style. It also is said that $23.9 \%$ of the variance in decision making originated from leadership style when the determination coefficient $(\mathrm{R} 2=0.239)$ is taken into consideration. (Fig. 2)

The data above shows that the role of leadership style is very influential on OCB. A school principal who pays attention to teacher performance will also improve the welfare of his teacher. Likewise, the decision making of a principal will determine the position of his subordinates, such as an increase in career paths, welfare, and entertainment for his teachers.

Organizational culture in schools that prioritize the security and safety, team-oriented, attention to detail and good communication patterns will improve teacher behavior in helping, tolerate and perform tasks more than expected that contributes to pre-school progress. Teachers in pre-school who can choose the best alternative in decision making will choose to carry out tasks to advance the pre-school through OCB [11].

\section{CONCLUSION}

The research proved that leadership style, decision making has a positive direct influence on OCB of the teacher in pre-school. Leadership style in schools that prioritize the security and safety, team-oriented, attention to detail and good communication patterns will improve the teacher behavior in helping, tolerating and performing tasks more than expected that contributes to pre-school progress. The teachers have the best alternative in decision making to carry out tasks through OCB. In addition, it also proved that the leadership style has a positive direct influence on decision making. Organizational culture in pre-school helps them in choosing the right decision in various activities and problem-solving. They will feel more comfortable, without the pressure in choosing the right decision through a predetermined process. Considering the research finding, it can be pointed out that in enhancing organizational citizenship behavior of the teacher in pre-school would be strengthened by leadership style and decision making.

The right headmaster's leadership style will encourage and facilitate the implementation of the duties of its members. In decision making which is the process of choosing the best alternative, it is very necessary to encourage, participate and support a leader so that members are able to make decisions right and accurately according to their capacity. A leader who does not give an opportunity to his members in making decisions according to the capacity of their members will have difficulties even though he has the knowledge and experience to carry out these decisions.
In a school environment, a school principal is required to have a role as the manager who is able to lead and guide the teachers to be independent in determining the best alternative in carrying out their job duties so that the role of the principal is very large for a teacher's decision making.

\section{ACKNOWLEDGMENT}

This research was supported by Prodi AdministrasiPendidikan, PascasarjanaUniversitasPakuan. We thank to Prof.DrIng. SoewartoHardhienata who provided insight and expertise that greatly assisted the research.

\section{REFERENCES}

1. H. Suharyati, T. Abdullah and B. Rubini, "Relationship between Organizational Culture, Transformational Leadership, Working Motivation to Teacher's Innovativeness,'International Journal of Managerial Studies and Research.vol. 4, no. 3, pp. 29-34, 2016.

2. J. Colquitt, J. A. Lepine, M. J. Wesson and I. R. Gellatly. Organizational Behavior: Improving Performance and Commitment in the Workplace. New York: McGraw-Hill, 2009..

3. S. L. McShane and M. A. Von Glinow.Organizational Behavior. New York: McGraw- Hill, 2008.

4. L. J. Mullins. Management and Organisational Behaviour. England: Pearson Educationa Limited, PrenticeHall, 2007.

5. D. L. Goetsch and S. B. Davis. Quality Management: Introduction to Total Quality Management for Production, Processing, and Services. New Jersey; Prentice Hall, Inc, 2000.

6. S. P. Robbins and T. A. Judge. Organizational Behavior. New Jersey: Pearson Education, 2009.

7. R. G. Owens. Organizational Behavior in Education: Adaptive Leadership and School Reform. Boston: Alyn and Baccon, 2006.

8. S. Certo,Modern Management. New Jersey: Prentice-Hall International, Inc, 1997.

9. R. Bogler and A. Somech. "Organizational citizenship behavior in school: how does it relate to participation in decision making ?" Journal of educational Administration, vol. 43, no. 5, pp. 420-438, 2005.

10. G. H. Laihad and R. Retnowati."The Effect of Organizational Culture And Decision Making Toward Organizational Citizenship Behavior of Teacher in Pre-School. Journal of Education, Teaching and Learning. vol. 3, no. 1, pp. 155-158, 2018. 